\title{
REFLECTIONS ON THE BEGINNINGS OF INFECTION CONTROL IN NSW
}

Greta Albera, Infection Control Sister (retired), Royal Alexandra Hospital for Children

Cathryn Murphy, Vice-president,

Infection Control Association (NSW) Inc

Dr Julian Gold, Chair, Department of Clinical

Epidemiology, Prince of Wales Hospital

The practice of infection control has become a major focus for health care workers in NSW, but the art and science of infection control has existed in this State for more than two decades. The Infection Control Association Inc. is the coordinating professional organisation for practitioners and interested health care staff and industry to share information and experiences. The history of this group reveals that many of the early problems and obstacles faced by infection control practitioners still exist.

Following international reports of nosocomial infection outbreaks in the 1960s, hospital authorities in NSW became increasingly aware of problems with nosocomial infection in their institutions and in 1965 began appointing trained nurses to monitor infection in hospital patients. The appointments were made on the hospital's own initiative.

The following list identifies the timing of the appointment and location of the pioneer Infection Control Sisters in the Sydney metropolitan area:

1965 Prince of Wales Hospital appointed the first Infection Control Sister

1967 Royal Alexandra Hospital for Children

1970 Concord Repatriation Hospital

1971 Sydney Hospital

1973 St George Hospital

1975 St Vincent's Hospital

1977 Royal Prince Alfred Hospital

1978 Liverpool Hospital

1978 Royal South Sydney Hospital

1978 Parramatta Hospital

1979 Manly District Hospital

1979 Blacktown Hospital

1979 Mona Vale District Hospital

1980 Westmead Hospital

The introduction of the Australian Council on Healthcare Standards Accreditation process in 1974 and NSW hospital participation in the process in 1977 led to a sharp rise in the number of Infection Control Sisters appointed. However, there were no official guidelines or policies outlining how to develop, coordinate and evaluate an infection control program. Practice was based largely on reviewing overseas literature and adopting the principles of other countries for NSW.

On October 16, 1973 four Sisters representing Sydney Hospital, St George Hospital, Royal Alexandra Hospital for Children and the host hospital, Royal North Shore, attended the first official meeting of Infection Control Sisters.

A second meeting held at the office of the NSW Nurses Association recommended that Infection Control Sisters should be responsible to the Director of Nursing for nursing issues and the Director of Microbiology for the technical aspects of the work and that a close liaison between medical and nursing staff should be established. This liaison remains an integral component of modern practice.

A November 1974 meeting discussed the establishment of an infection control committee for each hospital. The support and encouragement of policymakers was recognised at this early stage as being of crucial importance to all infection control practitioners.

In 1974, less than a handful of dedicated nurses formed the NSW Infection Control Group. The main objective of this group was to serve as a forum for sharing knowledge and experience in all aspects of infection control. The group was to be conducted under the auspices of the NSW College of Nursing. Meetings were held bimonthly and the meeting site rotated at venues offered by participating hospitals.

A March 1975 meeting of six Sisters established the following objectives of the group:

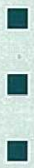

To improve patient care by education of hospital personnel in cross-infection;

To keep members informed of current medical and nursing literature on infection control; and

To further education in subjects relating to the work of the Infection Control Sisters.

The group recognised the importance of providing information to regional hospitals and decided to circulate a newsletter, which also enabled contact to be made with interstate colleagues. The NSW Infection Control Journal is circulated to about 400 members in Australia and overseas.

The pharmaceutical and chemical industries were supportive and were able to join as associate members. Industry support in the early days enabled members of the group to travel overseas to conferences and remains a valuable resource.

The Royal Alexandra Hospital for Children has consistently supported the NSW Infection Control Association and, in the association's infancy, provided support for convening and coordinating the first seminar of the group on November 12, 1977 .

The theme of the inaugural meeting - the battle against hospital-acquired infection - was explored by the 187 participants. The keynote speaker was Isobel Maurer, Principal Scientist at the Central Public Health Laboratories, London, and author of the book, Hospital Hygiene. Encouraged by the wide interest in the first Australia-wide infection control seminar, the group hoped to send a message not only to the few already converted, but further into the community.

The group's early office bearers believed infection control embraced a wider field than sterilisation and disinfection. Amalgamation with groups that focused solely on these areas was not pursued, but associate membership was offered and taken up by people working in related fields. Seminars were conducted annually as membership grew.

In January 1981 the Infection Control Group of NSW formulated its constitution and became the Infection Control Association NSW. The association was incorporated in 1990 .

The extension of infection control to the private sector in the early 1980s and the distribution of a Health Commission circular - Role of the Infection Control Sister in the Hospital Setting - indicated the growing importance of this discipline.

The original Infection Control Sisters recall fighting battles not only against hospital-acquired infection but also for recognition within the hospital hierarchy. Some aspects of 


\section{Infection control in NSW}

$\triangleright$ Continued from page 75

this battle pervade modern infection control practice and it is often only the well-publicised issues and more sensational stories about infection control that raise its profile.

In 1984 the Federal Government, through the Research and Development Grants Program (RADGA), provided $\$ 24,000$ for setting up the first national survey of nosocomial infections. The association was a key participant in the study, which involved collecting data on 28,643 patients in 269 hospitals in July 1984 . The survey provided benchmark nosocomial infection rates and has provided association members with useful comparative data for their institutions.

Gentamycin resistance was a problem in those days. For the first time, outbreaks of infection with gram-negative rods were noted. Disinfectants were also found to have become unsafe and growing bacteria. These findings had to be shared, yet there was a view that one should be loyal to one's workplace and not talk about any outbreaks.

The recognition of bloodborne diseases in the 1980s and 1990s has heralded a huge increase in the role and focus of infection control practice. Universal precautions, infection control committees, NSW Health policy and guidelines have become commonplace in today's health care setting. Despite the growth in information and resources relating to nosocomial infection, the problem of hospital-acquired infection persists and, in view of this, NSW Health is funding a Health Outcomes Project dealing with infection control. The project team is based at Prince of Wales Hospital.

This brief history indicates that, while the field is constantly growing and changing direction, basic skills are still required to function effectively. This is best summarised by the comment that involvement in infection controls needs "... a good knowledge of hygiene and the exercise of a lot of common sense and diplomacy in dealing with co-workers...".

In considering infection control today it should be remembered that the advanced position in NSW began with the efforts of a few dedicated nurses who fought for recognition.

\section{EDITORIAL COMMENT}

This is the first of an occasional series of articles on infection control issues. Contributions giving other perspectives on the history, development and practice of infection control in NSW are invited.

\section{PUBLIC HEALTH EDITORIAL STAFF}

The Bulletin's editorial advisory panel is as follows:

Dr George Rubin, Chief Health Officer, Public Health Division, NSW Health Department; Professor Stephen Leeder, Director, Department of Community Medicine, Westmead Hospital; Professor Geoffrey Berry, Head, Department of Public Health University of Sydney; Dr Christine Bennett, General Manager, Royal Hospital for Women; Dr Jane Hall, Director, Centre for Health Economics Research and Evaluation; and Director, Centre for Health Economics Research and

The editor is Dr Michael Frommer, Acting Director, Outcomes, Research and Development, NSW Health Department.

The Bulletin aims to provide its readers with population health data and information to motivate effective public health action. Articles, news and comments should be 1,000 words or less in length and include a summary of the key points to be made in the first paragraph. Please submit items in hard copy and on diskette, preferably using

WordPerfect 5.1, to the editor. Public Health Bulletin, Locked Mail

Bag 961, North Sydney 2059. Facsimile (02) 3919232.

Please contact your local Public Health Unit to obtain copies of the NSW Public Health Bulletin.

NEWS AND COMMENT

\section{MENTAL HEALTH POSTER}

In 1993 the Mental Health Branch produced a Directory of Mental Health Services in NSW to provide information on services. The directory was intended mainly for use by Health Department employees and non-government organisations.

It was found that for some individuals and groups such as general practitioners, police, probation and parole officers and some government departments a directory of all NSW services was not needed. The Mental Health Branch produced a simplified poster-format listing of local mental health services for each NSW Area and District. The poster shows:

- $\quad$ addresses and contact telephone numbers for Area chief executive officers, directors of psychiatry and Area coordinators, psychiatric hospitals, general hospital inpatient units, crisis/extended hours service, community mental health centres, child and adolescent inpatient services, rehabilitation/living skills services and authorised private hospitals; addresses and contact telephone numbers of nongovernment organisations providing mental health services; and multicultural services in each Area.

Contact the Mental Health Branch on (02) 3919307 for posters.

\section{LEAD IN PETROL}

In response to Dr Donald Scott-Orr's letter published in the April 1994 Public Health Bulletin, we would like to make clear that the benzene content of leaded petrol is essentially the same as that of unleaded petrol in Australia, in contrast to the situation in Europe. Therefore the conversion of the pre-1986 leaded fleet to regular unleaded petrol (ULP) is not expected to have an effect on benzene emissions, despite the absence of catalytic converters in pre- 1986 vehicles.

The use of premium unleaded petrol (PULP) is not encouraged on a wide scale as the use of PULP in noncatalyst vehicles would increase ambient benzene levels because of its greater benzene content. Sales of PULP are around 1.1 per cent of total petrol sales, and encouragement of its use has been recommended mainly in a small number of imported luxury vehicles. PULP costs significantly more than ULP (up to 10 cents/litre more) which precludes its use by the general market.

The Commonwealth Environment Protection Agency is using capital raised from the recently imposed excise differential on leaded fuel to fund studies to determine the best avenue to achieve further reduction of lead in leaded petrol, taking into account octane rating and additives to petrol. The Government is committed to making a decision on whether lead in leaded petrol in NSW will be reduced to 0.2 grams/litre at the end of 1994 . This decision is mainly dependent on the capacity of the leaded fleet to operate satisfactorily on reduced-octane fuel.

Christine Cowie and Stephen Corbett, Environmental Health, Food \& Nutrition Branch NSW Health Department 